\title{
都市における自然災害
}

\author{
—とくに崖崩れの危険度予知についての研究—
}

\section{STATISTICAL PREDICTION OF POSSIBILITY OF NATURAL DISASTER USING PHOTOGRAMMETRIC TECHNIQUE}

\author{
丸安隆和* - 清 水仁** - 嶋田厚二*** \\ By Takakazu Maruyasu, Hitoshi Shimizu and Koji Shimada
}

\section{1. まえがき}

最近わが国では人口の都市集中化がはげしく，このた め都市域は周辺の田園地帯や丘陵地帯に膨張し続けてい る。しかも，このような都市膨張に対して十分な計画が 伴わないため, 粗雑な宅地造成や不完全な施設等ともす れば安全性を軽視した無理な都市化がなされてきた。こ の結果, 多くの都市は災害に対してきわめて脆弱な体質 を露呈している。神戸, 横浜, 点の崖崩れ, 東京の中小 河川のはんらん等の例に見られるように, 家屋密集地帯 における半ば人為的な自然災害のもたらす被害はじん大 で, その防災問題は都市に拉ける重大な問題となりつつ ある。

こうした都会地での災害の要因は, 山地や大河川の場 合とくらべて著しく異なっており，災害の形態䇽よび機 構も, 山地などの場合とは本質的に異なった独得の傾向 を示している。従来, 山地や大河川の災害については, かなり多くの研究がなされているが，都市の災害につい て解明されているものはきわめてまれである。したがっ て, 都市防災に当っては, まず都市の自然災害のもつ特 質や機構を十分に把握し解析することが急務であると思 われる。

一方, これらの自然災害に対する従来の災害調査は, 災害の程度や復旧対策に重点が置かれ, 災害の原因など について調査が行なわれることがあっても，これらはほ とんどが災害の生じた後で事後処理のために行なわれる ものであった。また, これらの調査結果がその後の防㷋 対策に十分活用されるためには，調查は客観性をもった ものであることが必要であるが，この点についても必ず しも満足すべき方法がとられたとはいえないようであ る。

そこで, この研究は災害とその因子との相互関係を明 らかにし，都市内に散在する多数の危険箇所に対してお のおのその危険度を予知し，それに見合う防災対策を考 え, また新たな土地造成に対する資料を得るための合理

\footnotetext{
* 正会員 工博 東京大学教授 生産技術研究所

** 正会員 $\mathrm{KK}$ 大林組

*** 学生会員東京大学大学院学生
}

的な調查方式を確立しようとするのである。すなわち， この研究では, 横浜市の崖崩れ多発地帯の一部をサンプ ルとして, 航空写真からの情報の利用と統計的処理技法 を導入して “各地点の崖崩れに対する危険度を定量的に 表現する”ことを試み，これによって“各地点に行なう べき防災工事の必要度を順位づけ”，さらに “その適正 な規模を決定する”といら一連の解析方式を提案しよう としたのである。

自然災害は地形要因との関連がきわめて大きい。この 研究では, 地形認識のために航空写真から直接 “ベクト ル地形図”をつくり，これを解析に利用するといら新し い方式を導入した。従来なら地形図から読み取った地形 要因を, ベクトル地形図によって代用したことにより, 精度上の不安が取り除かれるだけではなく，場合によっ ては新しく地形図をつくるというばく大な時間と経費を 節減することができたし，またモデル化によって地形の 認識が容易になり, かつ一連の作業に電子計算機の利用 を可能し，作業が著しく簡易化されるといら利点が生じ た。

この研究は文部省統計数理研究所 青山博次郎博士の 指導のもとに行なわれたもので, さらに三木五三郎, 成 瀨洋, 山門明雄, 淵本正隆, 田浦秀春, 若村芳夫の各氏 に種々の資料や助言をいただき, 主として清水と嶋田が 取りまとめたものである。使用した航空写真はアジア航 測から提供され, 航空写真の測定は朝生郁三が行なっ た。各位に対して厚く謝意を表する。

\section{2. 調査地域の概況}

調查の対象とした横浜市の丘陵地帯は多摩丘陵の末端 部にあたり, 樹枝状に発達した浸食谷は, 急峻な傾斜で 平野部に臨んでいる。この地域には宅地造成が急速に進 み, それにつれて崖崩れの危険度が増大し, 近年集中豪 雨のたびに各所で多数の崖崩れが発生している。昭和 33 年 9 月には台風 22 号の影響で 2 日間に $321.2 \mathrm{~mm}$ の降雨を記録し, 1029 力所の崖崩れが発生し, 昭和 36 年 6 月の梅雨前線による集中豪雨では 6 日間にわたる $269.0 \mathrm{~mm}$ の降雨により 443 力所の崖崩れが発生してい る。また昭和 41 年 6 月の台風 4 号では, 2 日間にわた 
図-1 地 質 構 造

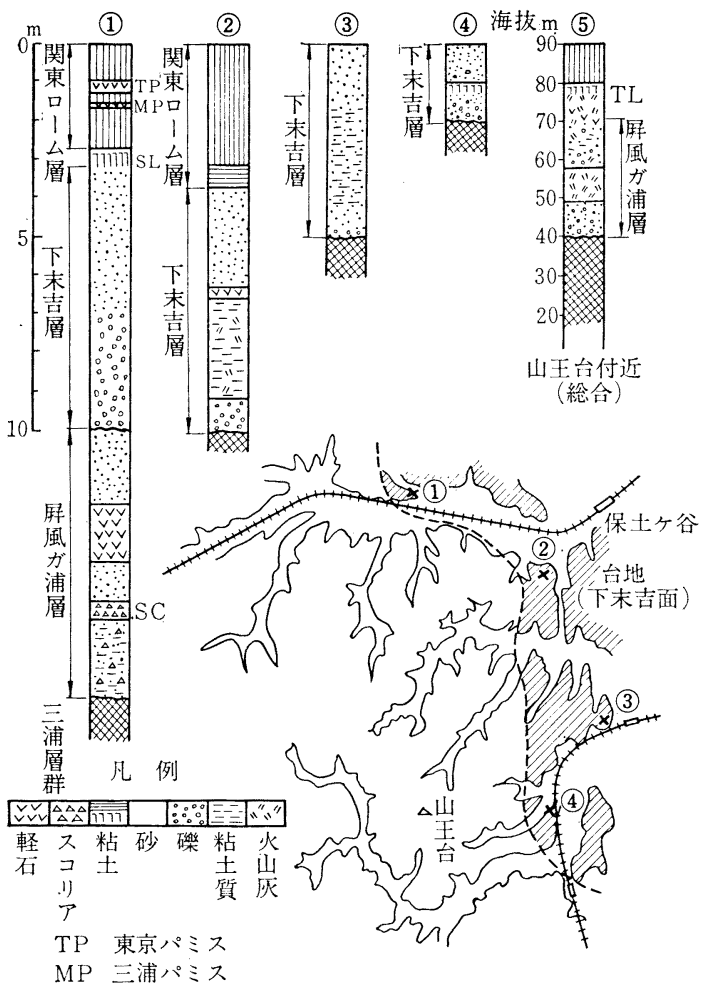

る $269.0 \mathrm{~mm}$ の降雨により 737 カ所の大小の崖崩れが 発生し, 大きな人的, 物的損害を与えた。

地質的にみると, これらの丘陵地帯は三浦層群とよば れる第三紀層を基盤とし, 上層に関東ローム層, その中 間に下末吉層, 屏風ガ浦層などの砂䃯層があり, いずれ も透水性の大きい層で構成されている（図一1)。台地部 分は下末吉層が上層にあり,この地域の崩れは三浦層群 を下透水層として含水比の大きな下末吉層がすべる場合 が多く, 丘陵部では関東ローム層あるいは屏風が浦層内 の砂䃯部分など, いずれの部分からでも崩れのおこる可 能性がある。この付近では崩れは表層の風化した部分 1 〜 $2 \mathrm{~m}$ だけでなく, 数 $\mathrm{m} の$ 深さにおよぶものもある。

この研究で対象にしたのは南区約 $2 \mathrm{~km}$ 四方の丘陵地 帯で急峻な谷筋にまで市街地化が進んでいる。横浜市消 防局の資料によると, 昭和 36 年および 41 年の崖崩れ はそれぞれ 22 力所, 38 力所あり, 地質構造は山王台付 近の地質構造図で代表され, 大体同じ条件のもとにある と考えてよい。

\section{3. 研究の進め方}

\section{(1) 研究の方法}

都市内の自然災害の研究においては, その災害の規模 は山地その他のものとくらべて著しく局地的であるた め, その調査は踏查を主とし, 航空写真の利用はそれほ ど一般的ではなかった。これに対し,この研究では航空
写真をフルに利用することを考えた。それは, 航空写真 は変化しつつある都市の状況をその撮影時点において正 確に記録し，それらの写真を実体観察することによっ て, 個々の崩壊地の局地的な地形その他の状況を把握で きるし, 調査全域についての地形, 水理, 土地利用など 崖崩れに関連する諸因子の調查も容易になるという利点 を考えたからである。さらに, 調査が広地域にわたると きは, 航空写真の利用は一層効果的になるであろう。こ のようにして得られた資料に統計的処理を加え, 危険度 を数量化して表現し, 客観的な判断が容易にできるよう にした。

また, 航空写真から測定した格子点標高から地形モデ ルを組立て, できるだけシンプルな形で, 地形的特徴を 抽出し解析を行なった。この方法によれば，精度の面で はまだ多くの問題を残しているが，地形の読み取りが簡 単になり，作業量を著しく軽減することができる。

この研究では大別してつぎの 3 段階にしたがって研究 が進められた。

a）第一段階 : 地形モデルの組立てと崖の認識

昭和 36 年の崖崩れの資料によれば, 大小 443 力所の 崩壊のらち自然崖が $79 \%$, 土木工事や宅地造成工事に よる人工崖が $21 \%$, 後者のうち盛土が $17 \%$, 切土が 4 \%と分類されている。ま

図-2 た, 崖崩れの中には, 図一 2 のAよらに斜面勾配が 急変する肩をもつ，いわゆ る崖だけではなく，Bのよ うに徐々に勾配が急にな り，その先端で相当急斜面 となって平坦部につながる ものも含まれる。したがっ て, この研究では人工崖, 自然崖を含めて斜面が平坦 地上 $4 \sim 5 \mathrm{~m}$ 以上の高さに わたって急斜面となってい
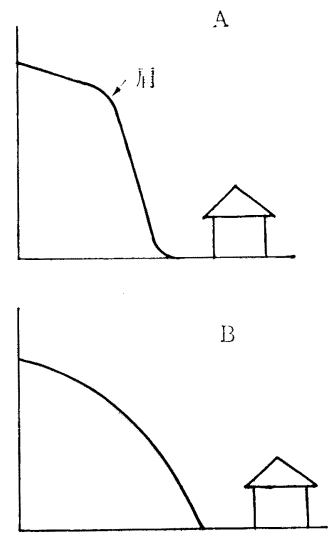
るものをすべて対象とした。A型の崖については航空写 真を実体視することによって容易に確認できる。自然崖 のうち相当な割合を占める B 型の崖は急斜面区間が短か く，対象とすべき斜面か否かを写真から直接判読するこ とが困難であった。それで調査地域を格子状の小ブロッ クに分割し, 地形を模型的に表現した地形モデルを作成 し, 斜面の地形的特徵を定量的，定性的に把握しやすい シンプルな形で表わし，崖崩れの対象となる地形ブロッ クを抽出することを試みた。

以上のように写真判読と地形モデルの組み合わせによ って第一段階の崖の認識作業を行なった。

b) 第二段階 : ブロック単位の危険度推定 第一段階で崖を認識されたブロックについて, 地形, 
地質，水理，土地利用などの諸因子を航空写真の判読お よび地形モデルによって把握し, これらの諸因子と崖崩 れの相互関係を明らかにし, 個々のブロックについて危 険度を数量的に推定する。

c）第三段階 : 精查

第二段階のデスクワークによって危険性が大である と判定されたブロック群からいくつかのブロックを無作 為に抽出して現地調査を行ない, 諸因子についての詳細 なデータを収集して，危険度を数量的に表わし，これを 現地調査による危険度判定の基準とする。

以上の作業工程はつぎに示すフローチャートにした がって行なわれた。

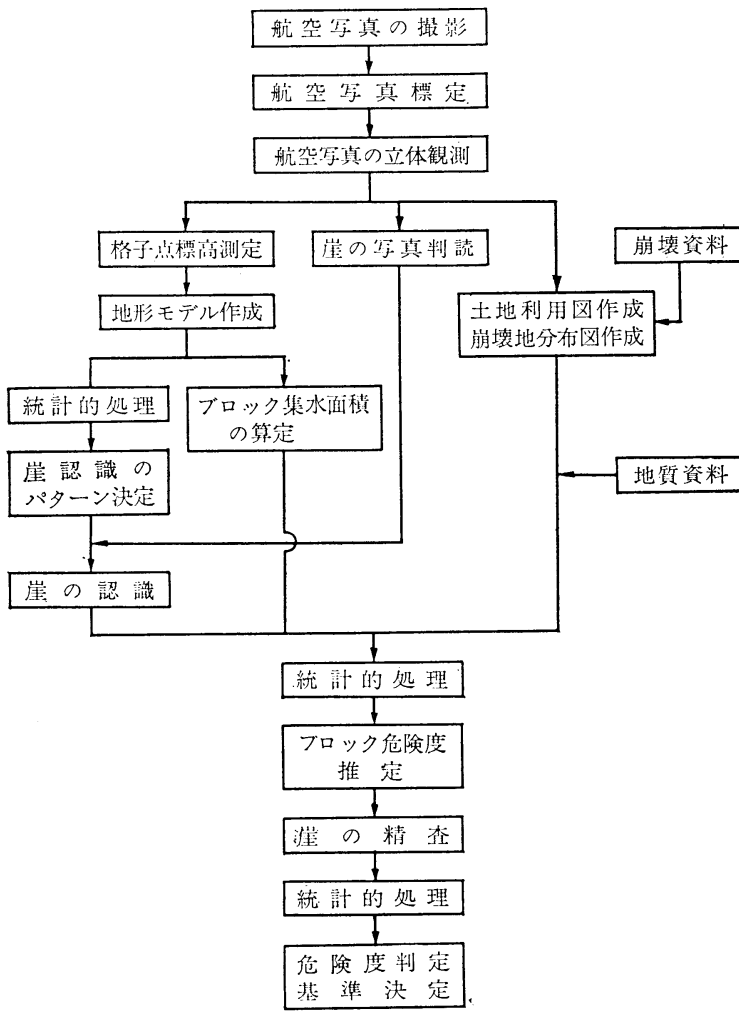

\section{(2) 航空写真の諸元}

\section{撮 影: 昭和 36 年 5 月 10 日}

縮 尺: $1 / 15000$

カメ ラ : RC 5 a $f=15 \mathrm{~cm}$ 画面寸法 $23 \mathrm{~cm} \times 23 \mathrm{~cm}$ フィルム：ケバルト 33

\begin{tabular}{|c|}
\hline 曼＜wide>影：昭和 36 年 10 月 29 日 \\
\hline メラ: RC $5 \mathrm{a} f=15 \mathrm{~cm}$ 画面寸法 $23 \mathrm{~cm} \times 23 \mathrm{~cm}$ \\
\hline
\end{tabular}

上記の資料は, この研究で使用した写真の諸元であ る。 5 月 10 日撮影の写真は, 崖崩れ前の状況を示す写 真であり，各因子の把握および格子点標高の測定に使用
した。10月 29 日撮影の写真は, 崖崩れ後の状況を示し ており，崖崩れ地点の判読および崖崩れ状況の観測に使 用したが，崩壊後 4 力月近く経過しているため，崩壊地 の多くは復旧され崩壊状沉の観察は困難であった。そこ で崩壊資料に示された崩壊地点を横浜市南区明細地図上 に拾い, 航空写真により崩壊地点の確認を行なった。

\section{（3）地形モデルの作成と崖の認識方法}

a) 地形モデルの作成

地形モデルによって，できるだけ実際の地形に近似さ せようとすると多数の点の座標值を必要とする。とくに 都市内の丘陵地帯の小規模な崖や勾配の変化状況を地形 モデルによって表現することは非常にむずかしい。この 研究では比較的粗い間隔の格子を組み，格子点の標高の データから単純な地形モデルを組立てた。この地形モデ ルと実際の地形との相互関係のパターンを把握して地形 の認識を行ならこととし，作成が容易で，必要な地形要 素の抽出が簡単なように，地形を多くの平面の集まりと した多面体で近似した。

地形モデル作成の作業はつぎのような手順で行なっ た。

調査地域に格子を組み，各格子点の標高を A 7 オ一 トグラフによって測定する。格子に囲まれた正方形の ブロックを一単位にして，各ブロックごとにそのブロッ クの有する 4 つの格子点から回帰平面を決定し, その回 帰平面をそのブロックの地形代表面とする。

この地形モデルから崖崩れに最も関連の深、斜面勾配 を把握するために, 各ブロックの回帰平面の最急勾配と その方向を求め，これを各ブロックの勾配および方向の 代表值とし，矢印の長さおよび方向でこれを示し，ベク トル地形モデル図を作成した。

この研究ではサンプルとして地域全域に対して $50 \mathrm{~m}$ 間隔の格子を組み，一部の地域に対しては $25 \mathrm{~m}$ 間隔の 格子を組んで，おのおの地形モデルを作成し，比較対象 した。 $50 \mathrm{~m}$ 間隔の格子の場合は小さな尾根や丘陵と平 地との境界を十分に表現することができないので，航空 写真から稜線, 丘陵末端線を入れて補った。図一3 は 50 $\mathrm{m}$ 格子, 図-4 は $25 \mathrm{~m}$ 格子の場合の同一地域に対する ベクトル地形図である。図一3，4 では単位勾配を 0.16 にとり，凡例に示したように 0.16 間隔で 4 段階に勾配 の大きさを分類して図示した。以上の一連の作業は下図 のような手順で作業を行ない，作業量の軽減をはかっ た。

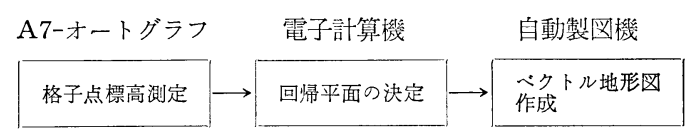

b）地形モデルによる崖の認識

都市内の丘陵地带の崖崩れ災害における人工崖の占め る割合はかなり大きく，また自然崖の崩壊と思われるも 
図一3 $50 \mathrm{M}$ 格子勾配ベクトル地形図

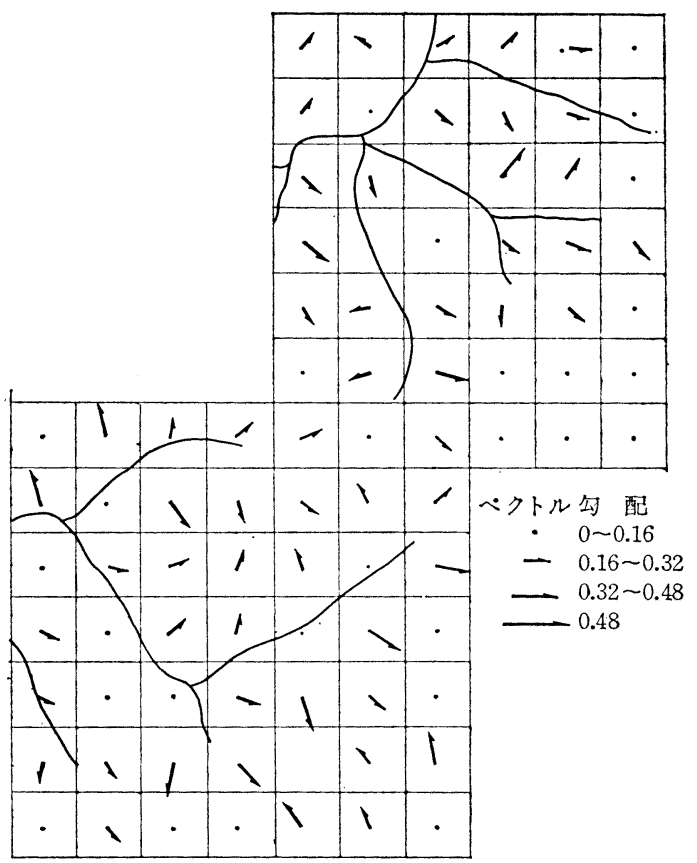

図一425 M 格子勾配ベクトル地形図

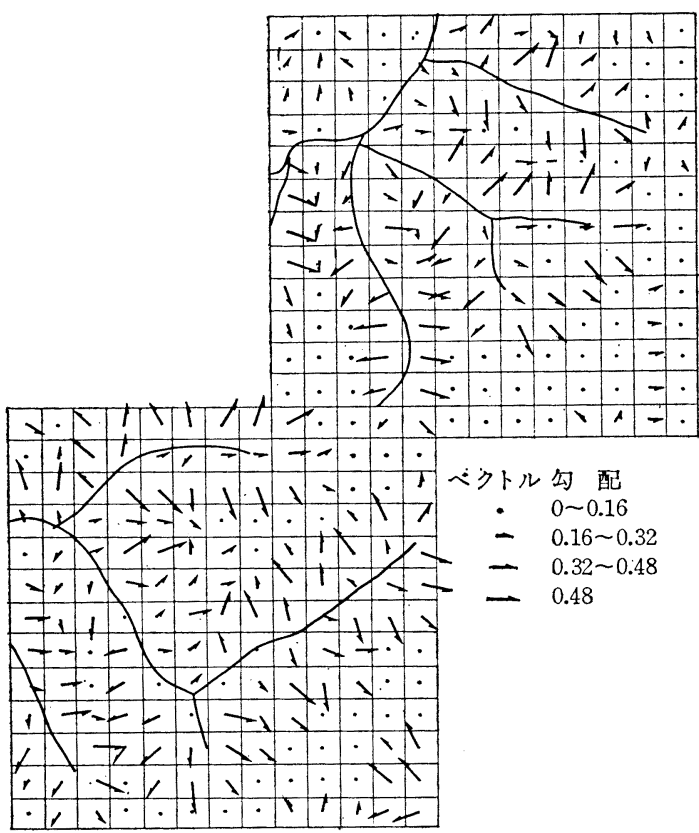

のでも長年にわたる都市化により，地形，水理等諸条件 に変化が生じ, 斜面が不安定となり, 豪雨時に崩壊を起 こしたと考えられる場合が多い。したがって抽出すべき 崖はその地域の地形,地質条件, 都市化の状況にしたがっ てその地域特有のパターンを有していると思われる。 横浜の場合, 急峻な尾根が枝状に平地部に延び，丘陵の 末端や浸食谷にまで宅地化が進んでおり，崖崩れの対象 となる斜面の大半はこのよらなところに集中している。
このような状況にある宅地の後背斜面はある程度の勾 配があれば，豪雨時にはどこからでも崩れる危険性のあ ることは直観的に予想できる。この研究では地形モデル によって表わされた地形的特徴と実際の崖の分布状況と の相互関係を統計的処理によって明らかにし, 崖分布の パターンを合理的に認識し，崖を有する可能性のあるブ ロックを識別しようとした。

このよらな方式によれば, この地域の崖の大半を占め る代表的なタイプの崖については容易に把握することが できる反面, 地形モデルが実際の地形をうまく表現して いない場合や例外的な地形状況の箇所に崖がある場合, これを抽出することは不可能であるという久点をもつ。 また崖の分布に関する地形パターンを決定するに当って サンプル地域に関する正確な地形図が必要であるが，こ の場合縮尺 $1 / 3000$ の市販の図を使った。この地図は平 面的な地物の関係位置に関する精度はかなりよいが，等 高線はシンプルな形で描かれており, 高さに関する精度 はあまり高くないことが予想される。

\section{（4）地形モデルによる集水域の算定}

崖崩れに対する誘因として最も大きい役割をもつのは 降水であり,この場合の崩壊機構にはつぎのようなもの が考えられる。

(i) 雨水の浸透によって土中の間げき水圧が増加す ると土の粒子間圧力が減少し, せん断抵抗が減少する。 その結果重力により斜面の土塊が下方に移動しようとす る力を土のせん断抵抗によってささえ切れなくなり崩壊 する。

（ii）表層の風化土層と下の岩盤あるいは固い土層と の間に一時的地下水流が発生し, 両層間の摩擦が著しく 減じて表層の崩壊を生ずる。

(iii) 谷状の地形では下方に行くにしたがって表流水 が集中して流れ, 表土を浸食洗掘して斜面の安定を減じ 崩壊の原因となる。

実際の崖崩れは以上の各原因が混合している場合も多 く，明確に区別できないこともあるが，いずれの場合で も, 雨水がどのような径路で移動し, 斜面にどの程度の 雨水が集まるかといらことが，崩壊に大きな関連を持っ ていると考えられる。

一般に斜面上の任意の点の降水は近似的に 表面流, 浸透流ともに最も勾配の大きな方向に斜面にそって下方 に移動し, 斜面の表面流量・浸透流量はその斜面の集水 面積に比例していると考えるこ とができる。この研究では地形 モデルから模型的に流線図を仮 定し, 各ブロックの集水面積を 推定した。

この場合, 図一5 に示すよう に格子点は点線で示された一辺

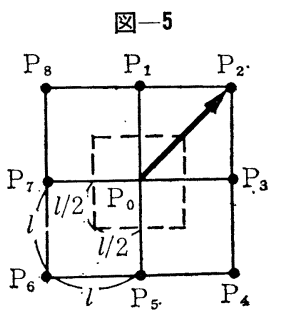


図一6 流 線 図

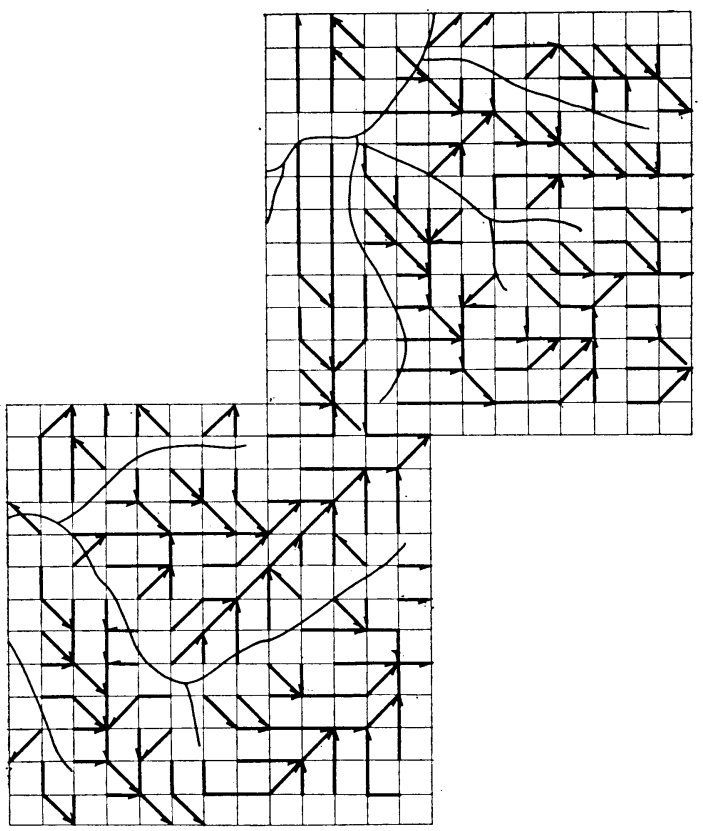

$l$ の正方形の地域を代表し,各格子点の雨水は周囲 8 点の うち最急下り勾配の方向にすべて移動するものとした。 たとえば $\overline{\mathrm{P}_{0} \mathrm{P}_{1}}, \overline{\mathrm{P}_{0} \mathrm{P}_{2}} \cdots \cdots . \overline{\mathrm{P}_{0} \mathrm{P}_{8}}$ のうち $\overline{\mathrm{P}_{0} \mathrm{P}_{2}}$ の勾配が最 大の勾配を示すとすれば，点 $\mathrm{P}_{0}$ の雨水はすべて $\mathrm{P}_{2}$ に 移動すると考える。図一6 は，この方式による $25 \mathrm{~m}$ 格 子の場合の流線図である。また分水界となっている稜線 付近の格子点から順次水の移動をたどって行けば，各格 子点の集水面積を算定することができる。

この場合ブロックに対する集水面積は近似的に 4 格子 点の集水面積の平均と考えられる。以上の作業は電子計 算機の利用により簡単に行ならことができる。

また，水の移動方向について回帰平面の最急勾配方向 を利用することも考えられるが，回帰平面は面の連続性 に難点があり，また取扱いが複雑であること，また回帰 平面自体の実際の地形に対する精度に限度があることな どにより格子点の生の標高データを用いて周囲 8 点のう ちのどこかへ進むとした場合とくらべて近似の程度に， それほど大差がないと考えられるので，取扱いの容易な 格子点標高を用いる方式を採用することにした。

\section{(5) 統計的処理方法}

崖の認識および危険度推定する場合統計的処理技術を 導入し，できるだけ主観に基づく判断を排して判定の定 量化に努めた。これらの過程はいずれも種々の因子か らある事象を予知することを目的としており，その統計 的処理方法は全く共通である。すなわち崖の認識におい ては “崖の存在する可能性”を予知しようとし危険度の 推定においては “崩壊の可能性” の予知を目的としてい る違いはあるが，その過程は同じである。
予知しようとする事象は各因子と線型的な関係にある ものと仮定する。各因子に対する重みを最もその事象を 予知しやすいように定め, 数值によって判定するのが目 的である。

いま，データ行列を $\boldsymbol{X}$ とし，個体 $i$ のデータ $X_{i, j k}$ が $j$ アイテム, $k$ カテゴリーに反応すれば 1 , しから ざれば 0 なる值をとるダミ一変数とし，アイテム数を $K$, 各アイテムの カテゴリー数を $M_{1}, M_{2}, \cdots, M_{k}$ と し，全個体数を $N$ とする。

$$
\boldsymbol{X}=\left[\begin{array}{ccc}
X_{1 \cdot 11} & X_{1 \cdot 12} \cdots \cdots \cdots X_{1} \cdot K M_{k} \\
X_{2 \cdot 11} & X_{2 \cdot 12} \cdots \cdots \cdots X_{2} \cdot K M_{k} \\
\vdots & \vdots & \vdots \\
X_{N \cdot 11} & X_{N \cdot 12} \cdots \cdots X_{N \cdot K M_{k}}
\end{array}\right]
$$

$\bar{X}_{j \cdot k}$ を $j$ アイテム, $k$ カテゴリーのデータの平均值 とすると

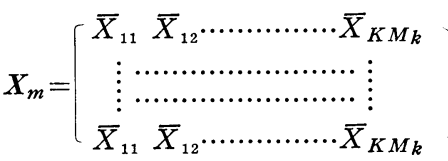

各因子に対する重みからなる列ベクトルを重みベクト ル $\omega$ とし, $\boldsymbol{Z}=\boldsymbol{X}-\boldsymbol{X}_{m}$ なる変換を行なう。

$\boldsymbol{f}=\boldsymbol{Z} \boldsymbol{\omega}$ と置く。 $\boldsymbol{f}$ を合成変量といい各変量の重みを 乗じ加え合せたものである。

合成変量の総平均は

$$
m=\frac{1}{N} \boldsymbol{i}^{\prime} \boldsymbol{f}=0 \text {. }
$$

ただし $\boldsymbol{i}$ は単位ベクトルとする。

合成変量の分散は

$$
V=\frac{1}{N} \boldsymbol{f}^{\prime} \cdot \boldsymbol{f}=\frac{1}{N}(\boldsymbol{Z} \boldsymbol{\omega})^{\prime}(\boldsymbol{Z} \boldsymbol{\omega})=\boldsymbol{\omega}^{\prime} \boldsymbol{R} \boldsymbol{\omega}
$$

ただし $\boldsymbol{R}=\frac{1}{N} \boldsymbol{Z}^{\prime} \boldsymbol{Z}$

いま, $l$ 組の個体群を指定して作った部分データ行列 を $Z_{1}, Z_{2}, \cdots, Z_{l}$ とすると

$$
\boldsymbol{Z}=\left[\begin{array}{c}
\boldsymbol{Z}_{1} \\
\boldsymbol{Z}_{2} \\
\vdots \\
\boldsymbol{Z}_{l}
\end{array}\right]
$$

と表わされる。

$N_{p}$ を第 $p$ 群に属する個体数とすると, 第 $p$ 群の平均 は

$$
m_{p}=\frac{1}{N_{p}} \boldsymbol{i}^{\prime} \boldsymbol{f}_{p}=\frac{1}{N_{p}} \boldsymbol{i}^{\prime} \boldsymbol{Z}_{p} \boldsymbol{\omega}
$$

となり, $\boldsymbol{m}^{\prime}{ }_{p}$ を第 $p$ 群の各変量の平均を成分とする列 ベクトルとすると

$$
m_{p}=\boldsymbol{m}_{p}{ }^{\prime} \boldsymbol{\omega}
$$

と表わせる。合成変量の分布の個体群間の分離を示す相 関比

$$
\eta^{2}=\sum_{p=1}^{l} \frac{N_{p}\left(m_{p}-m\right)^{2}}{N V}
$$

が最大となるように重みベクトルのを定めればよい。式 (1), (2), (3), (4) より 
$\eta^{2}=\sum_{p=1}^{l} \frac{N_{p}\left(\boldsymbol{m}^{\prime}{ }_{p} \boldsymbol{\omega}\right)^{2}}{N \boldsymbol{\omega}^{\prime} \boldsymbol{R} \boldsymbol{\omega}}=\sum_{p=1}^{l} \frac{N_{p} \boldsymbol{\omega}^{\prime} \boldsymbol{m}_{p} \boldsymbol{m}_{p}{ }^{\prime} \boldsymbol{\omega}}{N \boldsymbol{\omega}^{\prime} \boldsymbol{R} \boldsymbol{\omega}}$

ここで

$$
\boldsymbol{c}=\sum_{p=1}^{l} \frac{N_{p}}{N} \boldsymbol{m}_{p} \boldsymbol{m}_{p}^{\prime}
$$

と置くと

$$
\eta^{2}=\frac{\omega^{\prime} c \omega}{\omega^{\prime} R \omega}
$$

となる。 $\eta^{2}$ を $\boldsymbol{\omega}^{\prime} \boldsymbol{R} \boldsymbol{\omega}=1$ なる条件の下で最大とするには

$$
2 T=\boldsymbol{\omega}^{\prime} \boldsymbol{c} \boldsymbol{\omega}-\lambda\left(\boldsymbol{\omega}^{\prime} \boldsymbol{R} \boldsymbol{\omega}-1\right)
$$

とおき，

$$
\frac{\partial T}{\partial \omega^{\prime}}=c \boldsymbol{\omega}-\lambda \boldsymbol{R} \boldsymbol{\omega}=0
$$

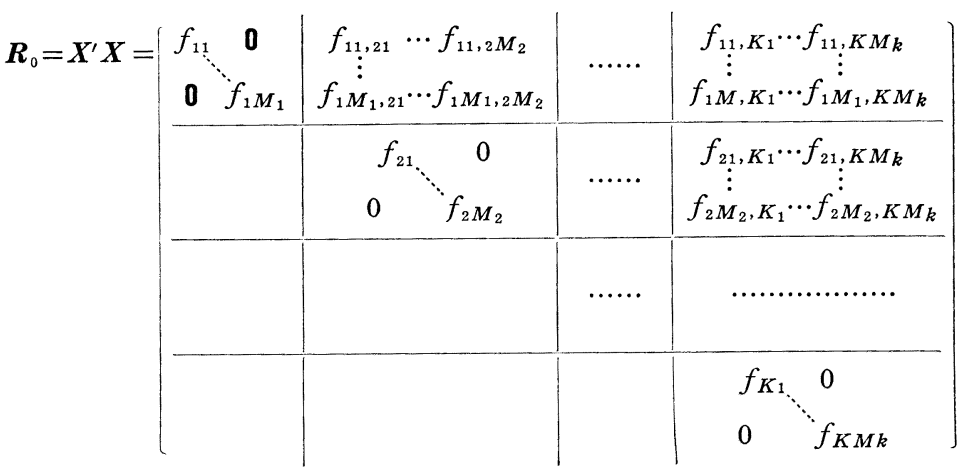

$$
\begin{array}{lr}
c=\sum_{p=1}^{l} \frac{N_{p}}{N} \boldsymbol{m}_{p} \boldsymbol{m}_{p}{ }^{\prime} & \frac{1}{N_{p}} \boldsymbol{i}^{\prime} \boldsymbol{X}_{p m}=\left[\bar{X}_{11} \overline{\boldsymbol{X}}_{12} \cdots \bar{X}_{K M_{k}}\right] \\
\boldsymbol{m}_{p}{ }^{\prime}=\frac{1}{N_{p}} \boldsymbol{i}^{\prime} \boldsymbol{Z}_{p}=\frac{1}{N_{p}} \boldsymbol{i}^{\prime}\left(\boldsymbol{X}_{p}-\boldsymbol{X}_{p m}\right) & \text { ただし, } \bar{X}_{j k, p} \text { を } j \text { アイム }, k \text { カテ } \\
& \text { のデータ平均值とする。 }
\end{array}
$$$$
\frac{1}{N_{p}} \boldsymbol{i}^{\prime} \boldsymbol{X}_{p}=\left[\bar{X}_{11 \cdot p}, \bar{X}_{12 \cdot p} \cdots \bar{X}_{K M_{k}, p}\right]
$$

$j$ アイテム, $k$ カテゴリー, $j^{\prime}$ アイテム, $k^{\prime}$ カテゴリ 一に反応する数を $f_{j k \cdot j^{\prime} k^{\prime}}$ とし, $j$ アイテム, $k$ カテゴ リーに反応する数を $f_{j k}$ とすると

を用いて

$$
\begin{aligned}
\boldsymbol{R} & =\frac{1}{N} \boldsymbol{Z}^{\prime} \boldsymbol{Z}=\frac{1}{N}\left(\boldsymbol{X} \boldsymbol{X}^{\prime}-\boldsymbol{X}_{m}^{\prime} \boldsymbol{X}-\boldsymbol{X}^{\prime} \boldsymbol{X}_{m}+\boldsymbol{X}_{m}^{\prime} \boldsymbol{X}_{m}\right) \\
& =\frac{1}{N}\left(\boldsymbol{X} \boldsymbol{X}^{\prime}-\boldsymbol{X}_{m}{ }^{\prime} \boldsymbol{X}_{m}\right)
\end{aligned}
$$

$$
\boldsymbol{c} \boldsymbol{\omega}=\lambda \boldsymbol{R} \boldsymbol{\omega}
$$

$$
\boldsymbol{Z}=\boldsymbol{X}-\boldsymbol{X}_{m}
$$

$0 \quad \ddots f_{K M k}$

ただし， $\bar{X}_{j k, p}$ を $j$ アイテム, $k$ カテゴリーの第 $p$ 群 のデータ平均值とする。

$f_{p, j k}$ を第 $p$ 群で $j$ アイテム, $k$ カテゴリーに属す るものの数とすると

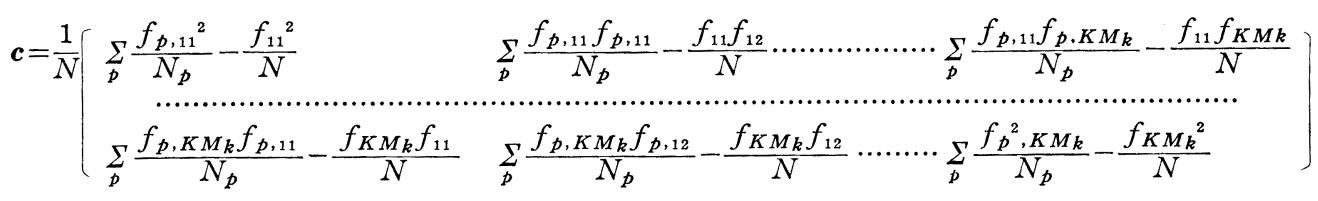

$p=2$ のときには

$$
\begin{aligned}
& \boldsymbol{c}=\frac{N_{1} N_{2}}{N^{2}}\left(\frac{f_{1,11}}{N_{1}}-\frac{f_{2,11}}{N_{2}}\right)^{2} \quad\left(\frac{f_{1,11}}{N_{1}}-\frac{f_{2,11}}{N_{2}}\right)\left(\frac{f_{1,12}}{N_{1}}-\frac{f_{2,12}}{N_{2}}\right) \ldots\left(\frac{f_{1,11}}{N_{1}}-\frac{f_{2,11}}{N_{2}}\right)\left(\frac{f_{1}, K M_{k}}{N_{1}}-\frac{f_{2, K M_{k}}}{N_{2}}\right) \\
& \left(\frac{f_{1}, K M_{k}}{N_{1}}-\frac{f_{2, K M k}}{N_{2}}\right)\left(\frac{f_{1,11}}{N_{1}}-\frac{f_{2,11}}{N_{2}}\right)\left(\frac{f_{1, K M_{k}}}{N_{1}}-\frac{f_{2, K M_{k}}}{N_{2}}\right)\left(\frac{f_{1,12}}{N_{1}}-\frac{f_{2,12}}{N_{2}}\right) \cdots\left(\frac{f_{1, K M_{k}}}{N_{1}}-\frac{f_{2, K M_{k}}}{N_{2}}\right)^{2}
\end{aligned}
$$

となる。

$$
\begin{aligned}
& \boldsymbol{a}^{\prime}=\left[\frac{f_{1,11}}{N_{1}}-\frac{f_{2,11}}{N_{2}} \quad \frac{f_{1,12}}{N_{1}}-\frac{f_{2,12}}{N_{2}} \cdots \cdots \cdots\right. \\
& \left.\frac{f_{1, K M_{k}}}{N_{1}}-\frac{f_{2}, K M_{k}}{N_{2}}\right]
\end{aligned}
$$

とすると

$$
\boldsymbol{c}=\frac{N_{1} N_{2}}{N^{2}} \boldsymbol{a} \boldsymbol{a}^{\prime}
$$

総平均 $m=\frac{1}{N} \boldsymbol{i}^{\prime} \boldsymbol{X} \boldsymbol{\omega}=0$ とすれば $\boldsymbol{X}_{m} \boldsymbol{\omega}=0$ となる。
したがって $\boldsymbol{R} \boldsymbol{\omega}=\frac{1}{N}\left(\boldsymbol{R}_{0}-\boldsymbol{X}^{\prime} \boldsymbol{X}_{m}\right) \boldsymbol{\omega}=\frac{1}{N} \boldsymbol{R}_{0} \boldsymbol{\omega}$

一方, $\boldsymbol{a}^{\prime} \boldsymbol{\omega}=\left(\boldsymbol{m}_{1}-\boldsymbol{m}_{2}\right)^{\prime} \boldsymbol{\omega}=m_{1}-m_{2}$

すなわちスカラー量となる。

ゆえに, $\boldsymbol{R}_{0} \boldsymbol{\omega}=\boldsymbol{a}$ なる連立方程式を解けば求める重み

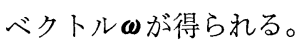

このようにして定めた諸因子の重みのを用いて各個体 について, 得点として合成変量 $f_{i}$ を求めれば一次元的に 表わされる。 $f_{i}$ の代りに変数として $f$ と書き, $f$ の第 一群および第二群における分布をおのおの密度関数 $g_{1}$ 
$(f), g_{2}(f)$ とする。判定の基準 $f_{0}$ を定めて個体に対 する得点が $f_{0}$ より大きいならば第一群に属し， $f_{0}$ より 小ならば第二群に属すると判定するものとする。

いま任意に $f_{0}$ を定めると, 判別の的中率 $p$ は

$$
p=\frac{N_{2}}{N} \int_{-\infty}^{f_{0}} g_{2}(f) d f+\frac{N_{1}}{N} \int_{f_{0}}^{\infty} g_{1}(f) d f
$$

となる。 $p$ を最大にするには， $N_{1}, N_{2}$ がわかっている 時には

$$
\frac{N_{1}}{N} g_{1}\left(f_{0}\right)=\frac{N_{2}}{N} g_{2}\left(f_{0}\right)
$$

なるように $f_{0}$ を選べばよい。

一方 $N_{1}, N_{2}$ が未知の場合にはミニマックス理論によ って $f_{0}$ を定める。 $N_{1}$ が $p$ に最も不利になる場合を想 定し，その場合において最もよい的中率が得られるよう に $f_{0}$ を定めるのである。このような意味での $p$ の最も よい值を

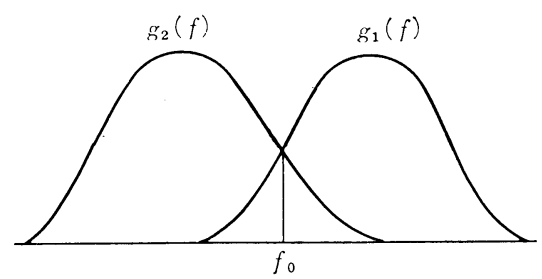

$$
p_{0}=\max _{f_{0}} \min _{N_{1}} p
$$

とすれば

$$
p_{0}=\int_{-\infty}^{f_{0}} g_{2}(f) d f=\int_{f_{0}}^{\infty} g_{1}(f) d f
$$

なる $f_{0}$ を求めればよい。

この研究では $N_{1}, N_{2}$ が末知の場合への適用を目的と しているので, 後者のミニマックス法により $f_{0}$ を定め た。

\section{4. 崖の認識}

\section{(1) 崖の 認識}

この研究では数 $\mathrm{m}$ の高さの斜面が, 急傾斜で平坦部に 臨んでいるものを崖と定義した。崖と定義したものには つぎの種類がある。

（1）肩をもつもの：傾斜が急に変化する部分があ り，そこから急勾配で平地部に臨んでいるもので，普通 に崖とよばれるもの。

（2）屃のないもの：斜面の傾斜が徐々に変化し，明 瞭な肩がなく，どこまでを崖とするかが困難であるが， 下部ではわずかな部分が相当急傾斜となっているもの。

（3）宅地造成地の小規模な人工崖：人工崖であって も大規模な切土部分は (1) の形態となっているものが多 い。宅地造成地では, 斜面を階段状に切土もしくは盛土 し，高さ数 $\mathrm{m}$ におよぶのり面をつくっている例が多く， 粗雑な造成地ではこの部分の崩壊が多い。前二者にくら べて崩壊規模は著しく小さいが，このような路面も崖に
含めることにした。

この研究では崖の斜面判読に縮尺 $1 / 15000$ という小 縮尺の写真を使用したため，小規模な崖や不安定な急斜 面を確認することは非常に困難であった。とくに分類 （2）の急斜面は，この地域の急峻な浸食谷にはありふれ た地形であり，小縮尺写真の場合や樹木のある場合，微 妙な地形上の特徴からこれらを抽出することは困難であ る。そこでここでは, 凧の存在を崖の判読基準とした。

\begin{tabular}{|c|c|c|c|c|c|}
\hline \multicolumn{6}{|c|}{ 表一1 } \\
\hline $\mathrm{H}$ & $4 \mathrm{M}$ & $6 \mathrm{M}$ & $8 \mathrm{M}$ & $10 \mathrm{M}$ 以上 & 計 \\
\hline (I) 写真判読 & 23 & 19 & 8 & 44 & 94 \\
\hline (II) 地 形 図 & 115 & 83 & 28 & 65 & 292 \\
\hline 摘 & \multicolumn{5}{|c|}{ 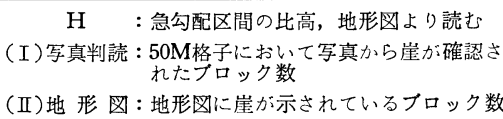 } \\
\hline
\end{tabular}
すなわち, 写真判読では分類 (1) の崖を認識することに した。写真判読結果を斜面の高さによって表一1 のよう に分類した。

急勾配区間の高さが $4 \mathrm{~m}, 6 \mathrm{~m}$ については, 分類 (2), （3）の占める割合が大きく，判読率は低い。急勾配区間 が $8 \mathrm{~m}, 10 \mathrm{~m}$ 以上の場合はかなり顕著な崖であり, 高 い判読率が期待されたが，写真縮尺の小さいこと，樹木 のため斜面形状が明瞭でないところがあったこと，判読 技術が不足であったこと，などのため判読率は比較的低 かった。これは上述の条件を改善することにより，相当 向上し得るものと思われる。

\section{（2） $50 \mathrm{~m}$ 地形モデルによる崖の認識}

前節で示したように判読による崖の抽出率は低かった ので, 地形モデルに示された地形的特徵と実際の崖の分 布状況との相互関係を明らかにし，崖の存在に関する地 形パターンを決定して, 崖の存在する可能性の大である ブロックを抽出する方法をとった。 $50 \mathrm{~m}$ 地形モデルは 約 $2 \mathrm{~km}$ 四方の地域にわたって作成したが，全面積の約 40\%を占める平地部を除外し, 丘陵部 1024 ブロックを 対象とした。

崖の認識にあたっては，まず地形モデルにより地形パ ターンを求め, 崖のあるブロック群と崖のないブロック 群を分離する。さらに，崖がないと判定されたブロック 群に判読によって崖の存在が認められたものについて は，崖のあるブロック群に移して修正を行なった。

地形的特徵を示す因子 (アイテム) として (1) 勾 配，(2) 地形構造，(3) 稜線，(4) 丘陵末端線の 4 つを 用いた。 $50 \mathrm{~m}$ 地形モデルは格子閒隔は大であるため, 地形を平均化する回帰平面の欠点が強く現われ，隣接し た二つの格子点が谷や稜線の反対側にきて, 谷や稜線が 全く表現されない場合もある。したがって (1)，(2)， 他に（3），(4）を補助因子として加えた。 
各アイテムをつぎのようなカテゴリーに分類して集計 した。

（I） 勾配 (1) 勾配 0.48 以上のもの

(2) 勾配 0.32 以上 0.48 末満のもの

(3) 勾配 0.16 以上 0.32 未満のもの

(4) 勾配 0.16 末満のもの

(II) 地形構造

(1)

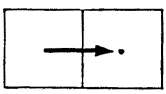

(2)

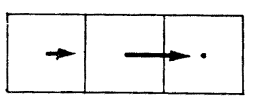

(3)

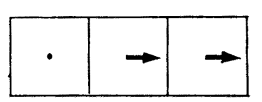

(4)

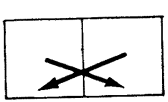

（5）（1＜wide>〜（4）のカテゴリーのいずれにも属さない 場合。

（III）稜線（1）ブロックに稜線あり

(2) ブロックに稜線なし

(IV) 丘陵末端線 （1）ブロックに丘陵末端線あり （2）ブロックに丘陵末端線なし

以上の各アイテム各カテゴリーについて分類集計し, (3-5)に示した係数を示す対称行列 $\boldsymbol{R}_{0}$ および定数項と なる行列 $\boldsymbol{a}$ を作成すると表一2 のようになる。 $\omega_{25}=\omega_{31}$ $=\omega_{42}=0$ と置いて $\boldsymbol{R}_{0} \boldsymbol{\omega}=\boldsymbol{a}$ なる連立方程式を解くと,
重みベクトルいはつぎのようになる。

$\left[\begin{array}{l}\omega_{11} \\ \omega_{12} \\ \omega_{13} \\ \omega_{14} \\ \omega_{21} \\ \omega_{22} \\ \omega_{23} \\ \omega_{24} \\ \omega_{25} \\ \omega_{31} \\ \omega_{32} \\ \omega_{41} \\ \omega_{42}\end{array}\right]=\left(\begin{array}{r}-10.7 \\ -6.7 \\ -4.4 \\ -12.3 \\ 7.4 \\ 14.3 \\ 4.8 \\ 0.9 \\ 0 \\ 0 \\ 4.2 \\ 8.5 \\ 0\end{array}\right)$

この重みベクトルから得点を計算し, 第一群, 第二群 に分類し, 得点別に分布状況を集計すると表一3のよう になりこれを確率分布グラフで示したものが（グラフ 一1) である。さらに両群の判定の的中率をほぼバラン スさせるために，(グラフー2）に示したように第一群は 高い得点から, 第二群は低い得点から順次累積確率を求 め, 両群の累積確率グラフの交点付近に判定基準 $f_{0}$ を 定めた。

判点基準 $f_{0}$ を 2.5 とし, 得点が 2.5 より大であれ

$$
\text { 表-3 }
$$

\begin{tabular}{|c|c|c|c|c|c|c|}
\hline \multirow[b]{2}{*}{ 得 点 } & \multicolumn{3}{|c|}{ 第一群(崖のあるブロック群) } & \multicolumn{3}{|c|}{ 第二群(崖のないフロック群) } \\
\hline & 個数 & 確率分布 & 累積確率 & 個数 & 確率分布 & 累積確率 \\
\hline$-10 \sim-15$ & 7 & $2.4 \%$ & $100.0 \%$ & 47 & $6.4 \%$ & \\
\hline$-5 \sim-10$ & 37 & 12.5 & 97.6 & 310 & 42.3 & $48.7 \%$ \\
\hline $0 \sim-5$ & 20 & 6.9 & 85.1 & 94 & 12.8 & 61.5 \\
\hline $0 \sim 2.5$ & 29 & 10.0 & 78.2 & 65 & 8.9 & 70.4 \\
\hline $2.5 \sim 5.0$ & 45 & 15.5 & 68.2 & 62 & 8.5 & 78.9 \\
\hline $5.0 \sim 10.0$ & 61 & 21.0 & 52.7 & 89 & 12.2 & 91.1 \\
\hline $10 \sim 15$ & 70 & 24.1 & 31.7 & 45 & 6.2 & 97.3 \\
\hline $15 \sim 20$ & 20 & 6.9 & 7.6 & 18 & 2.5 & 99.3 \\
\hline $20 \sim 25$ & 2 & 0.7 & & 2 & 0.2 & 100.0 \\
\hline 計 & 291 & 100.0 & & 732 & 100.0 & \\
\hline
\end{tabular}

表-2

\begin{tabular}{|c|c|c|c|c|c|c|c|c|c|c|c|c|c|c|c|c|c|}
\hline & & & & & & & & $\boldsymbol{R}_{0}$ & & & & & & & & & \\
\hline & & & & & & & & II & & & & & & & $f_{1, j k}$ & $f_{2, j k}$ & $a$ \\
\hline 因子 & 1- & 1 & 2 & 3 & 4 & 1 & 2 & 3 & 4 & 5 & 1 & 2 & 1 & 2 & & & \\
\hline I & $\begin{array}{l}1 \\
2 \\
3 \\
4\end{array}$ & 15 & 191 & 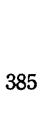 & 432 & $\begin{array}{r}8 \\
83 \\
183 \\
0\end{array}$ & $\begin{array}{r}0 \\
43 \\
63 \\
0\end{array}$ & $\begin{array}{r}2 \\
20 \\
61 \\
0\end{array}$ & $\begin{array}{r}3 \\
22 \\
33 \\
0\end{array}$ & $\begin{array}{r}2 \\
23 \\
45 \\
432\end{array}$ & $\begin{array}{r}1 \\
64 \\
94 \\
62\end{array}$ & $\begin{array}{r}14 \\
127 \\
291 \\
370\end{array}$ & $\begin{array}{r}2 \\
42 \\
55 \\
34\end{array}$ & $\begin{array}{r}13 \\
149 \\
330 \\
398\end{array}$ & $\begin{array}{r}4 \\
74 \\
163 \\
50\end{array}$ & $\begin{array}{r}11 \\
17 \\
222 \\
382\end{array}$ & $\begin{array}{r}-13 \\
945 \\
2569 \\
-3500\end{array}$ \\
\hline II & $\begin{array}{l}1 \\
2 \\
3 \\
4 \\
5\end{array}$ & & & & & 274 & 106 & 83 & 0 & 502 & $\begin{array}{l}78 \\
16 \\
25 \\
15 \\
87\end{array}$ & $\begin{array}{r}196 \\
90 \\
58 \\
43 \\
45\end{array}$ & $\begin{array}{l}61 \\
13 \\
11 \\
14 \\
34\end{array}$ & $\begin{array}{r}213 \\
93 \\
72 \\
44 \\
468\end{array}$ & $\begin{array}{r}118 \\
60 \\
30 \\
17 \\
66\end{array}$ & $\begin{array}{r}156 \\
46 \\
53 \\
41 \\
436\end{array}$ & $\begin{array}{r}1924 \\
1433 \\
307 \\
24 \\
-3688\end{array}$ \\
\hline III & $\begin{array}{l}1 \\
2\end{array}$ & & & & & & & & & & $\begin{array}{r}221 \\
0\end{array}$ & $\begin{array}{r}0 \\
802\end{array}$ & $\begin{array}{l}41 \\
92\end{array}$ & $\begin{array}{l}180 \\
710\end{array}$ & $\begin{array}{r}56 \\
235\end{array}$ & $\begin{array}{l}165 \\
567\end{array}$ & $\begin{array}{r}-330 \\
330\end{array}$ \\
\hline IV & $\begin{array}{l}1 \\
2\end{array}$ & & & & & & & & & & & & $\begin{array}{r}133 \\
0\end{array}$ & $\begin{array}{r}0 \\
890\end{array}$ & $\begin{array}{r}64 \\
227\end{array}$ & $\begin{array}{r}69 \\
663\end{array}$ & $\begin{array}{r}1257 \\
-1257\end{array}$ \\
\hline
\end{tabular}



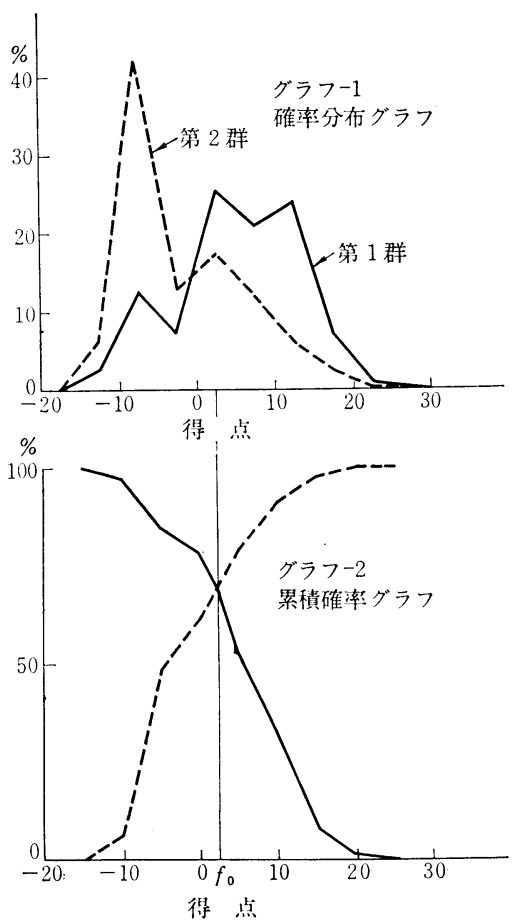

ば第一群に, 2.5 より小であれば第二群に属すると判定 すれば判定の的中率は第一群 $68 \%$, 第二群 $71 \%$, 全体 では 70\% となる。実際には崖があるのに第二群に属す ると判定された 138 ブロック中, 写真判読によって確認 されたものが 39 ブロック含まれており，これらを第一 群に移すと的中率は第一群については $81 \%$, 全体では $74 \%$ となる。

$50 \mathrm{~m}$ 地形モデルにおける崖の存在を示す地形パター ンは, 構造については丘陵末端の斜面を示すカテゴリー （1）または見掛上肩を形成していることを示すカテゴリ 一(2)の重みが大となり，勾配についてはカテゴリー （2）または（3）に属する場合の重みが大となっている。 また補助因子として加えた稜線付近の重みが小となり, 丘陵末端線については，これを含むブロックの重みが大 となっており, 地形構造によって示されたパターンが強 調されている。

一方, 標高差数 $10 \mathrm{~m}$ 内外の 丘陵地で 50 $\mathrm{m}$ 間隔の格子を用いると, 尾根末端付近など では回帰平面が著しく平均化され，勾配が 0.48 以上になる場合が非常に少なくなって いる。この研究で $50 \mathrm{~m}$ 格子を適用した地域 では，勾配が 0.48 以上のカテゴリーに属す るブロックは 1023 の中わずか 15 ブロッ クに過ぎない。

このよらにサンプル サイズが著しく小さ くなっている項目に関しては母集団の性質が サンプルにそのまま現わされていない場合が

多く, 推定の信頼度も薄い。この研究で勾配 0.48 以上 の重みが著しく小さくなっているのは 15 個のブロック 中にたまたま崖が少なかったためと推定される。

また，カテゴリーの重みの較差によって各因子の影響 の強弱を推定すると，崖の存在に最も大きい影響を与え るものは地形構造の因子と考えられる。

\section{（3） $25 \mathrm{~m}$ 地形モデルによる崖の認識}

$50 \mathrm{~m}$ 地形モデルは格子間隔が大であることに起因す ると思われる欠点を持っているため, これを比較する目 的で $25 \mathrm{~m}$ 地形モデルを作成し，解析を行なった。

地形パターンの決定に当っては（I）勾配，（II）地 形構造の二つの因子を用いた。両因子をつぎのカテゴリ 一に分類した。

ＩI］勾配 $50 \mathrm{M}$ 地形モデルの場合と同様のカテゴ リーとする。

[II] 地形構造

(1)

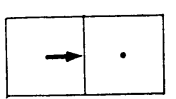

(2)

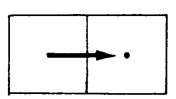

勾配 $0.16 \sim 0.32$ のブロ ックの下方に勾配 0.16 以下のブロックが接続し ているもの。

形態は (1) と同様である が，勾配が 0.32 以上の 急斜面の場合。 カテゴリー(1)および(2)は丘陵末端線を示す。

(3)

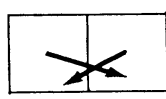

(4)

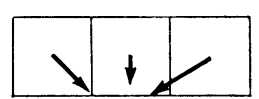

(5)

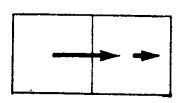

(6)

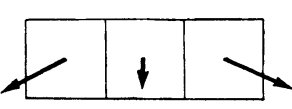

$\mathrm{V}$ 字型の谷の側斜面を示 す。

U字型の谷の側斜面を示 す。

（3）より谷の規模が大で ある。

斜面途中で下方に緩勾配 のブロックを接続してお り, 斜面中腹での勾配変 化を示す。比較的幅の広

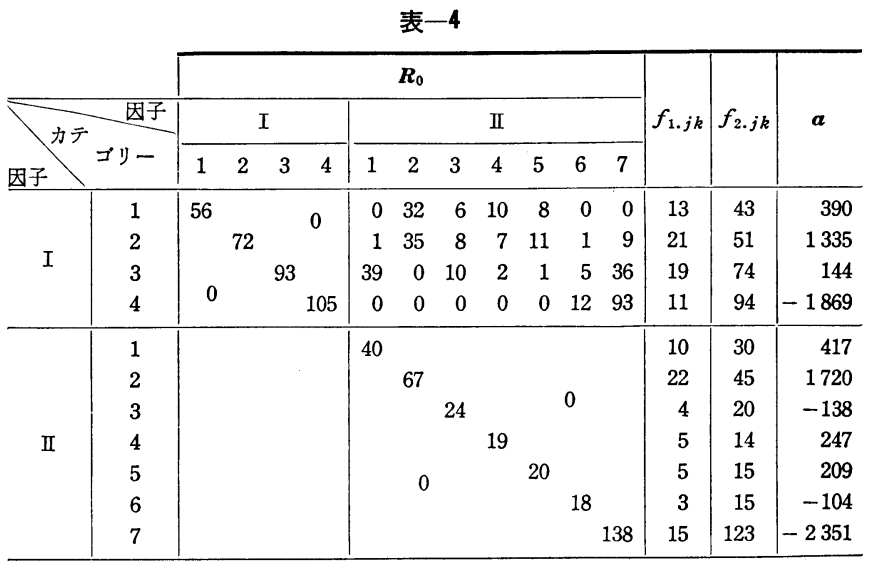


い屋根上のブロックであ

ることを示すもの。

（7）（1）（6)のいずれのカテゴリーにも属さないも の。

以上の各因子各カテゴリーについて 分類集計し， $\boldsymbol{R}_{0}$ および $\boldsymbol{a}$ を表一4 のように作り， $\boldsymbol{R}_{0} \boldsymbol{\omega}=\boldsymbol{a}$ なる連立方 程式を解いて各因子各カテゴリーの重みを求めた。

$\omega_{27}=0$ と置いてこの連立方程式を解くと重みベクトル はつぎのようになる。

$$
\left[\begin{array}{l}
\omega_{11} \\
\omega_{12} \\
\omega_{13} \\
\omega_{14} \\
\omega_{21} \\
\omega_{22} \\
\omega_{23} \\
\omega_{24} \\
\omega_{25} \\
\omega_{26} \\
\omega_{27}
\end{array}\right]=\left[\begin{array}{r}
-38.6 \\
-19.3 \\
-11.1 \\
-19.3 \\
21.7 \\
54.5 \\
15.1 \\
41.8 \\
37.3 \\
11.3 \\
0
\end{array}\right]
$$

表一4 によれば勾配に関してはカテゴリー (4), (3), (1)，(2) の順で崖の存在率は大になっており，ほぼ妥当 な結果を示している。因子 $[I]$ と $[I I]$ は独立でない こと総平均を 0 と置いたことなどから，因子 $[I]$ の重 みはすべて負になっている。 $25 \mathrm{~m}$ 地形モデルの場合， 崖存在の地形パターンを $50 \mathrm{~m}$ 格子の場合と比べると, 勾配因子でカテゴリー（1）に属するもののうち約 6 割 が，地形構造因子ではカテゴリー（2）に分類され，崖が あると判定されている。横浜の地形条件からも崖の存在 可能性が大であると予想される谷の地形については， $50 \mathrm{~m}$ 格子では重みが小という結果となったが， $25 \mathrm{~m}$ 格 子の場合は, V字型よりU字型の谷の場合重みが大きく なっている。これはU字型谷では人工的な地形改変のた めの不安定になっている箇所が多いためと思われる。ま た， $25 \mathrm{~m}$ 格子の場合も，地形構造が支配的因子となっ ている。

この重みベクトルより得点を集計し, 各群における得 点別の分布状況を表一 5 およびグラフー3 に示した。グ ラフー4 に示した累積確率グラフから判定規準 $f_{0}$ を 10

\begin{tabular}{|c|c|c|c|c|c|c|}
\hline & \multicolumn{6}{|c|}{ 表一5 } \\
\hline & \multicolumn{3}{|c|}{ 第一群(崖のあるプロック群) } & \multicolumn{3}{|c|}{ 第二群(崖のないプロック群) } \\
\hline 点 & 個数 & 確率分布 & 累積確率 & 個数 & 確率分布 & 累積確率 \\
\hline$-20 \sim-30$ & & & & 7 & $2.7 \%$ & \\
\hline$-10 \sim-20$ & 13 & $20.3 \%$ & $100.0 \%$ & 125 & 47.8 & $50.5 \%$ \\
\hline $0 \sim-10$ & 5 & 7.8 & 79.7 & 23 & 8.7 & 59.2 \\
\hline $0 \sim 10$ & 5 & 7.8 & 71.9 & 20 & 7.6 & 66.8 \\
\hline $10 \sim 20$ & 26 & 39.1 & 64.1 & 57 & 21.8 & 88.6 \\
\hline $20 \sim 30$ & 3 & 4.7 & 25.0 & 5 & 1.9 & 90.5 \\
\hline $30 \sim 40$ & 12 & 20.3 & & 25 & 9.5 & 100.0 \\
\hline 計 & 64 & 100.0 & & 262 & 100.0 & \\
\hline
\end{tabular}

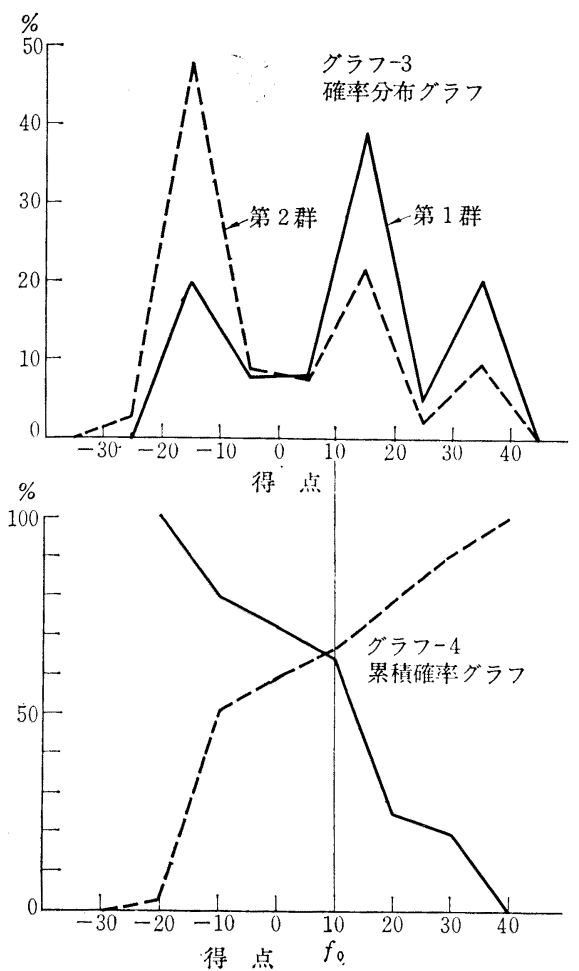

に定めると判別の的中率は第一群“崖のあるブロック群” については 64\%, 第二群 “崖のない群”については $67 \%$ よっている。

\section{（4）両地形モデルの比較および問題点}

$25 \mathrm{~m}$ 格子の場合, $50 \mathrm{~m}$ 格子の場合にくらべて両群の 分離の状況は悪く, 的中率も $50 \mathrm{~m}$ 格子で $70 \%, 25 \mathrm{~m}$ 格子で $66 \%$ となっている。これはサンプルサイズの 相違によるのが大きな原因となっていると思われる。

実際には崖があるにかかわらず崖がないと判定された ブロックについてその内容を検討してみるとつぎのよう になる。 $50 \mathrm{~m}$ 格子については, 地形が著しく平均化さ れて尾根などを全く表現していない場合や $25 \mathrm{~m}$ 格子に すればほぼ納得のいく重みとなっている谷や急勾配のブ ロックなどの場合のように，格子間隔を小とすればある 程度判定が改善されると思われるものが $37 \%$ を占めて いる。また 4.(1) で分類した宅地造成地の小崖が $50 \mathrm{~m}$ 格子で $28 \%, 25 \mathrm{~m}$ 格子では $65 \%$ となっている。

宅地造成地の小崖については, 地形モデルにより推定 することは不可能に近く, 大縮尺の写真により確認する ことを検討すべきであろら。

したがって, 判定の精度を高めるには, 今後つぎの 2 点について研究を進めてゆくことが必要である。

（1）写真判定技術の向上および大縮尺写真による検 討

（2）実際の地形をより近似できる地形モデルの開発 


\section{5. ブロック危険度の判定}

\section{（1）危険度に関する諸因子}

地形モデルによって把握した地形因子扔よび航空写真 から読みとった諸因子と崩壊との相互関係を統計的処理 によって明らかにし, 各ブロックに対する危険度の判定 を行なった。ブロック危険度の判定は, 統計的な取扱い によってあらかじめ危険度の予知を行なった後で, 必要 に応じて精査に行ない，その確度を高めるという方法を とった。

この研究では $1 / 15000$ および $1 / 25000$ という小縮尺 の写真を使用したことと，写真判読の技術に慣れていな かったことなどから，写真に記録された諸情報を十分に 生かすことができず，わずかに土地利用状況についての み写真から判読した。また，地質条件については，2.で 述べたように崩壊に対してはほぼ同一条件下にあると考 えられるので，ここでは地質因子は省略した。

つぎの因子について, 各カテゴリーを定め解析を進め た。

［I］勾配, [II ] 地質構造, [III] 稜線, [IV] 丘 陵末端線

[I ] [IV] の地形因子に対しては, 両地形モデルとも
崖の認識において定めたのと同様のカテゴリーとする。

[V] 土地利用

（1）市街地，(2) 造成地，(3) 田・畑，(4) 丘 陵 (樹木), (5) 丘陵 (草地)

カテゴリーは上記の $5 つ と し ， 2$ 種以上の土地利用が 認められる場合には面積の広いものをとった。

[VI] 斜面上方に隣接するブロックの土地利用

斜面の水理条件などは上方の土地利用の影響を受けて いると考えられる。カテゴリ一は [V] と同様である が，(6) 稜線に近く上方にブロックがない場合を加え た。

[VII $]$ 斜面方向

台風時などで, 強風に伴われた雨の斜面崩壊に与える 影響は，斜面方向によって著しい差が認められる。この 因子として回帰平面の最急勾配の方向を取り上げ，つぎ の 4 つのカテゴリーに分類した。

(1) $\mathrm{N} \sim \mathrm{E}$, (2) $\mathrm{E} \sim \mathrm{S}$, (3) $\mathrm{S} \sim \mathrm{W}$, (4) $\mathrm{W} \sim \mathrm{N}$

[VIII] 集水面積

地形モデルによって算定したブロック集水面積をつぎ の 5 つのカテゴリーに分類した。
(1) $18.75 \mathrm{a}$ 末満
(2) $18.75 \mathrm{a} \sim 37.5 \mathrm{a}$
(3) $37.50 \mathrm{a} \sim 62.50 \mathrm{a}$
(4) $62.5 \mathrm{a} \sim 93.75 \mathrm{a}$

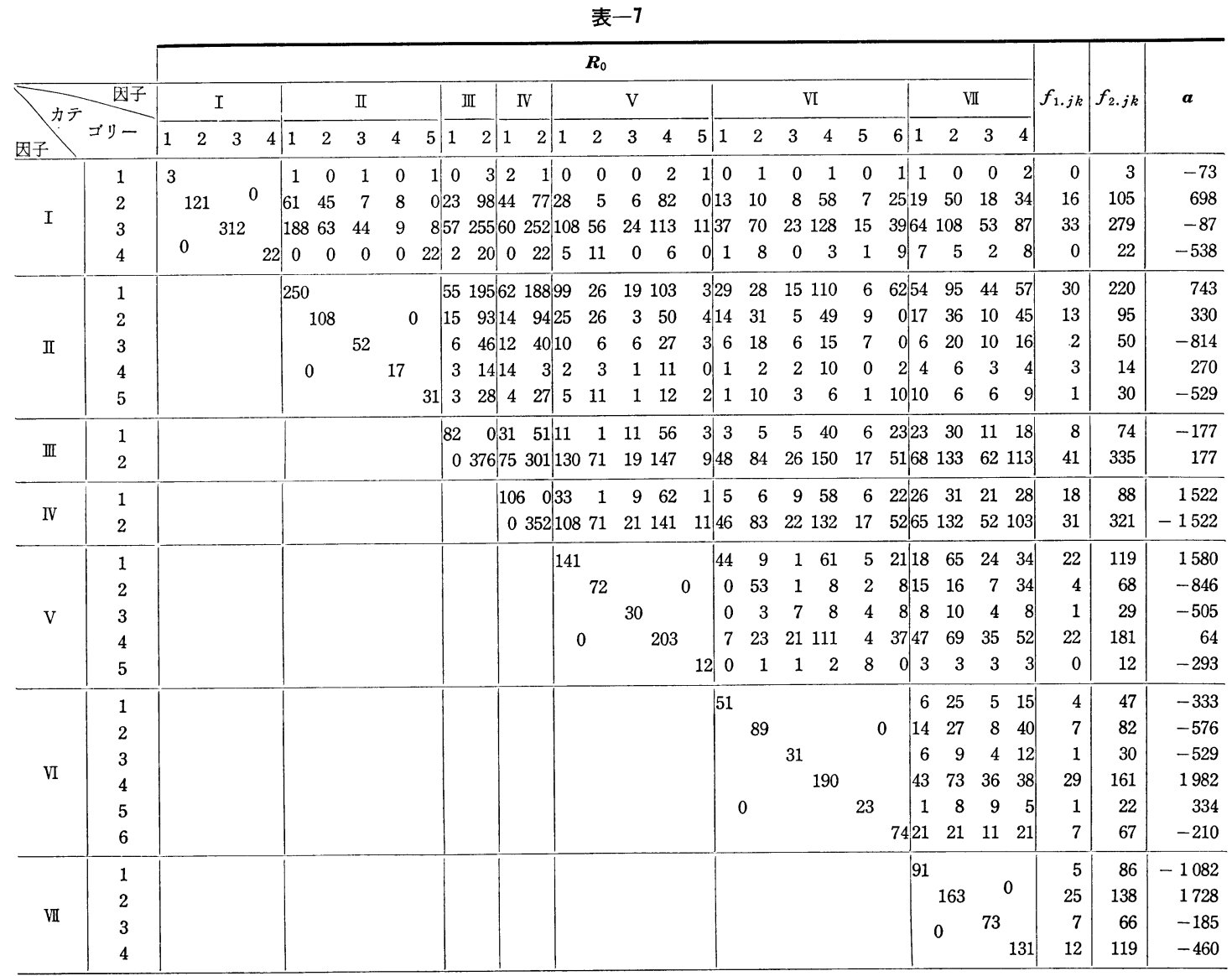


(5) $93.75 \mathrm{a}$ 以上

集計分類に当って，同一ブロック内の 2 カ所で崩壊が 発生している場合または, 同一籄所において, 昭和 36 年, 41 年の 2 回にわたって崩壊している場合には, そ のブロックの重みを 2 倍と考えて処理した。

\section{（2） $50 \mathrm{M}$ 地形モデルによる危険度の推定}

$[\mathrm{I}],[\mathrm{II}],[\mathrm{III}],[\mathrm{IV}],[\mathrm{V}],[\mathrm{VI}],[\mathrm{VII}]$ の諸因子 について分類集計し, 行列 $\boldsymbol{R}_{0}, \boldsymbol{a}$ を表一7 のように作 成し, $\omega_{23}=\omega_{31}=\omega_{42}=\omega_{52}=\omega_{62}=\omega_{71}=0$ と置いて $\boldsymbol{R}_{0} \boldsymbol{\omega}=$ $\boldsymbol{a}$ なる連立方程式を解くと重みべクトルはつぎのように なる。

この重みベクトルによると勾配の因子に関しては, カ テゴリー（2）勾配 $0.32 \sim 0.48$ および (3) 勾配 0.16 〜0.32 の危険度が大となり，カテゴリー（1）勾配 0.48 以上および (4) 勾配 0.16 以下の危険度が小となって いる。勾配の最も大きいカテゴリー（1）の危険度が小と なっているのは, このカテゴリーに属するブロック数が 少ないためで, カテゴリー（1）と（2）は統合すべきであ ったと思われる。

地形構造, 稜線, 丘陵末端 線の因子については，いずれ も丘陵末端および谷の危険度 が大となっている。地形構造 のカテゴリー (5) の重みが大 となっているが，勾配因子の カテゴリー (4) との相関性が 強く矛盾した判定にはならな w。

土地利用の因子に関して は，市街地化されているブロ

\begin{tabular}{|c|c|c|c|c|c|c|}
\hline \multirow[b]{3}{*}{ 得 } & \multicolumn{5}{|c|}{ 表一9 } & \\
\hline & \multicolumn{3}{|c|}{ 第一群（崩 壊） } & \multicolumn{3}{|c|}{ 第二群（非崩壤） } \\
\hline & 個数 & 確率分布 & 累積碓率 & 個数 & 確率分布 & 累積確率 \\
\hline$-45 \sim-55$ & & & & 1 & $0.2 \%$ & \\
\hline$-35 \sim-45$ & & & & 10 & 2.4 & $2.6 \%$ \\
\hline$-25 \sim-35$ & & & & 23 & 5.6 & 8.2 \\
\hline$-15 \sim-25$ & 3 & $6.1 \%$ & $99.9 \%$ & 57 & 14.0 & 22.2 \\
\hline$-5 \sim-15$ & 3 & 6.1 & 93.8 & 93 & 22.7 & 44.9 \\
\hline$-5 \sim 5$ & 5 & 10.2 & 87.7 & 79 & 19.3 & 64.2 \\
\hline $5 \sim 7.5$ & 4 & 8.2 & 77.6 & 27 & 6.6 & 70.8 \\
\hline $7.5 \sim 15$ & 11 & 22.4 & 69.4 & 39 & 9.6 & 80.4 \\
\hline $15 \sim 25$ & 12 & 24.5 & 47.0 & 46 & 11.2 & 91.6 \\
\hline $25 \sim 35$ & 7 & 14.3 & 22.5 & 25 & 6.1 & 97.7 \\
\hline $35 \sim 45$ & 4 & 8.2 & & 9 & 2.2 & 99.9 \\
\hline 計 & 49 & 199.9 & & 409 & 99.9 & \\
\hline
\end{tabular}

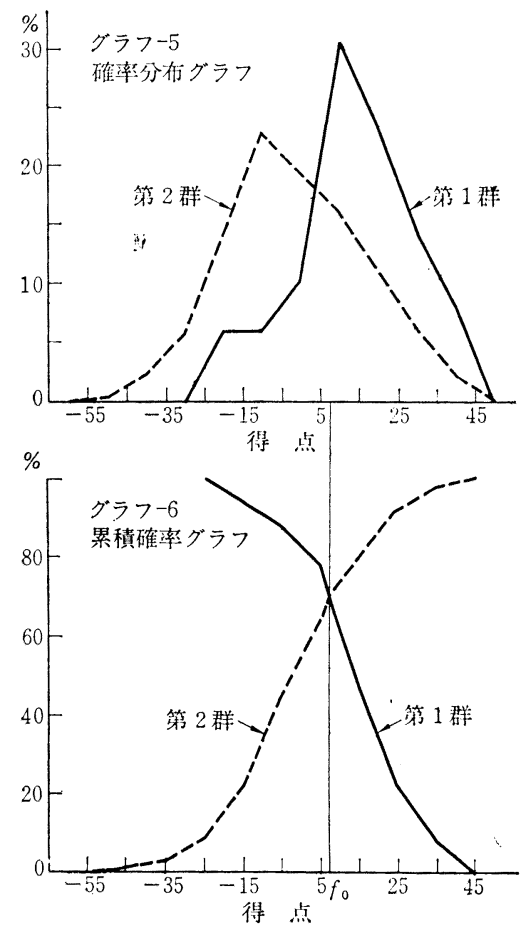

の分布状況を示した。グラフー6 の累積確率グラフより 判定基準を 7.5 に定めると，判定の的中率は $71 \%$ とな る。

\section{（3）危険度推定における問題点}

この研究では, 地形モデルから得られた諸因子および 土地利用など, 限られた数の因子からブロック危険度の 推定を行なっており, また土質, 防災のための構筑物な ど重要な因子を欠いているため，判定の的中率も $70 \%$ にとどまっている。昭和 36 年の災害調查集計によれ ば, 441 カ所の崩壊箇所中, 擁壁不備によるもの $41 \%$, 排水不良によるもの $64 \%$ となっており，これらの要因 は今後十分考慮すべきことを示している。

しかし，航空写真によって，これらの因子をある程度 把握することが可能であれば, 現地踏查を行なわないで 一応の高い水準で危険度の推定ができると思われる。

重みベクトルから各ブロックの得点を算出し， 表一 およびグラフー5 に崩壞ブロック群, 非崩壊ブロック群 
この可能性としてつぎのようなことが考えられる。

1）大縮尺写真の使用

2） カラー写真または赫外線写真等の利用 これらについては, 今後の研究に待つほかはない。

\section{6. 精査の方法}

\section{(1) 概 説}

航空写真から得られた諸因子によって危険性が大であ ると判定された箅所については，一応防㷋工の有無，土 質, 予想される被害の程度などについて重点的な精査を 行ならことが必要となる。

上述のように, 航空写真による推定の的中率は十分高 いものではないから，危険率大であると判定された崖で も，実際に崩壊したものとそうでないものとの差異をよ く調査し, より精度の高い危険度判定の基準を定めるこ とも必要である。

この目的のために, いくつかの崖をサンプルとして選 び，選ばれたサンプルに対して現地調查を行なう。つぎ に各因子に適当なカテゴリーを設定して，データを分類 集計し, 統計的処理によって, 各因子各カテゴリ一の危 険度を求め, 現地調查の危険度判定の基準の決定を行な 5。

サンプルを選ぶには, ブロック危険度推度の際作成し た崩壊ブロック群と非崩壊ブロック群とから, 無作為に 抽出する。これらのブロック内にある不安定な斜面と崩 壊箇所を精查の対象とするのである。

\section{(2) 精查の方法}

崩壊に影響する諸因子について，表一10 のような項 目について調査することが必要と思われる。

\section{表-10}

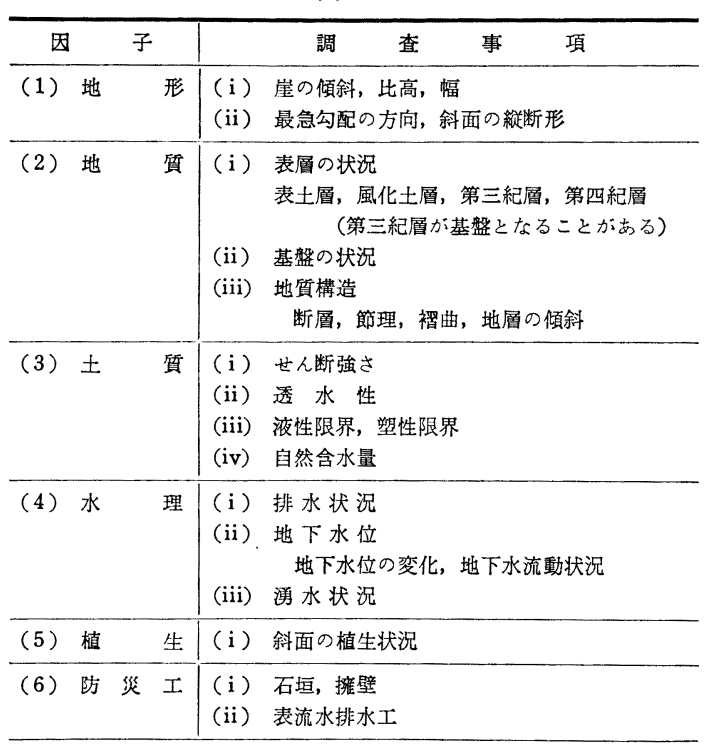

以上のような調査データを整理し，各因子ごとにいく つかのカテゴリーを設定し, 統計的処理により各因子各 カテゴリーごとの得点および判定基準を決定する。現地 調查において, 調査結果とカードの各因子各カテゴリー の該当欄に記入し，同時に得点を加算すれば，現地で直 ちに危険度を予測することができる。

\section{7. 被害程度の予想}

崖崩れの被害程度は崩壊の規模と家屋その他の施設の 密集状況によって左右され, 被害程度を推定するに当っ てはまず崩壊規模を予想する必要がある。

現時点では, 斜面の崩壊機構を諸因子と関連づけて, その概略を定性的に推定しているに過ぎず，崩壊規模， 形態を理論的根拠によって定量的に把握することは困難 と思われる。

一方理論的な崩壊機構はともかくとして, 崩壊状況, 崩壊規模, 崩壊地の諸因子についての資料をできるだけ 収集することによって，統計的な処理により，その相互 関係を明確にすることができると考えられる。したがっ て, 災害の調查は, その目的と調查項目を明確に決め, あとの統計的処理が有意に行なえるように計画され，実 施されることが望ましい。これらの点については，今後 さらに研究開発を進め, より合理的な防災計画, 防災投 資が行ならことができるようにしなければならないと考 える。

\section{参 考 文 献}

1) 芝祐 順: 行動科学に於る相関分析法, 昭和 42 年 11 月, 東大出版会

2) 青山博次郎: ダミ一变数と数量化法への影響, 昭和 40 年 4 月, 統計数理研究所

3）青山博次郎 : 市場調査のための数量化の理論と実際, 昭 和 37 年, 工業統計講座 (7) 統計数理研究所

4）丸安隆和：写真判読による地すべり崩壊の統計的研究, 土木学会論文集 116 号, 昭和 40 年 4 月

5）稻見悦治：都市災害論序説，昭和 41 年 5 月，古今書院

6) 小出 博: 山崩机 [応用地質], 炤和 38 年 8 月, 古今書 院

7）小貫義男 : 土木地質，昭和 32 年 3 月，森北出版

8）三木五三郎：地盤調査の実務，昭和 42 年 6 月，オーム 社

9）大滝俊夫 : 横浜市内のがけくずれの予報, 昭和 36 年 11 月, 研究時報 $14(7)$

10）大滝俊夫: 降雨によるがけくずれの水文学的研究, 昭和 11 年 7 月, 研究時報 17 (6)

11）田中 茂: 神戸市背山地域の崩壊箇所の予想について, 昭和 37 年 5 月, 建設工学研究所

12）横浜市役所 : 横浜市地域防災計画

（1968. 4. 4 ·受付） 